\title{
Awareness regarding Menstrual Hygiene among Girl Students of a School in Chitwan
}

Krishna Bahadur Raut, ${ }^{1}$ Roshani Agrawal Khatry, ${ }^{2}$ Tumla Shrestha ${ }^{3}$

'Department of General Practice and Emergency, Chitwan Medical College, Bharatpur, Chitwan, Nepal, ${ }^{2}$ Department of Nursing, Patan Academy of Health Sciences, Lalitpur, Nepal, ${ }^{3}$ Department of Nursing, Maharajgunj Nursing campus, Maharajgunj, Kathmandu, Nepal.

\section{ABSTRACT}

Introduction: Adolescent girls often lack knowledge regarding reproductive health including menstruation which can be due to socio-cultural barriers in which they grow up. It is important to educate adolescents about issues related to menstruation so that they can safeguard themselves and hold implications for professionals involved in improvement of reproductive health. The main objective of the study was to find out awareness regarding menstrual hygiene among girl students of a school in Chitwan.

Methods: A descriptive cross-sectional study was conducted in a school in Chitwan among girl students of school from grade 8,9 and 10 from 2019 July to August 2019 after ethical approval. All the girl students from grade 8, 9 and 10 were included into the study. Data were entered and calculations were using Statistical Package for the Social Sciences version 20.

Results: Among 184 adolescent girls, 156 (84.8\%) were aware about the menstrual hygiene and most of them $176(95.7 \%)$ knew about the criteria of ideal absorbent to be used during menstruation. Likewise, 120 (65.2\%) were aware regarding washing the genital organs, 137 (74.5\%) were changing sanitary pad and $136(73.9 \%)$ were disposing used sanitary pad. The mean age of girl students was $14.48 \pm 1.259$ years respectively.

Conclusions: Awareness regarding menstrual hygiene was present among the girl students, but practice for proper menustral hygiene was low compared to studies done in similar settings.

Keywords: adolescent; awareness; hygiene; menstruation.

\section{INTRODUCTION}

Menstruation is the periodic discharge of blood and mucosal tissue from the uterus and vagina.

Different studies in Tanzania and Nigeria has shown most of the women use toilet tissue or cloth instead of sanitary pads. ${ }^{2,3}$ Between $31 \%$ and $56 \%$ of Nigerian school girls have been found as using toilet tissue or cloth to absorb their menstrual blood as opposed to menstrual pads. ${ }^{3}$ Nearly half of the adolescent girls had not known of the origin of menstrual and had unhygienic practices and misconceptions. ${ }^{4}$

Correspondence: Dr. Krishna Bahadur Raut, Department of General Practice and Emergency, Chitwan Medical College, Bharatpur, Chitwan, Nepal. Email: drrautkrishna@gmail.com, Phone: +9779841516491. 
Women spend around six to seven years of their lives menstruating as a result key priority should be given for the necessary knowledge, facilities and cultural environment to manage menstruation hygienically and with dignity for women and girls.In reality, the importance of hygiene during menstrual period is highly neglected. ${ }^{5}$

The main objective of the study was to find out awareness regarding menstrual hygiene among girl students of a school in Chitwan.

\section{METHODS}

A descriptive cross-sectional study design was done at Shree Narayani Vidyamandir Madhyamik Vidyalaya, Shivanagar, Chitwan, Nepal from 2019 July to August 2019 after ethical approval. Data was collected continuously during the study period. Whole population of girl students from grade 8 to10 were taken into study who already had their menarche. Self-administered structured questionnaire was used to collect data collection within adolescent students of class 8, 9 and 10. Total Sample size was 184 who had already menarche.

Verbal and written consent were also taken from the respondents during this study. The collected data was checked, reviewed and organized for completeness. Data was entered and calculations for binary data was done along with frequency and proportion using SPSS version 20 .

\section{RESULTS}

Most 156 (84.8\%) of the respondents were aware about the menstrual hygiene and most of them 176 $(95.7 \%)$ knew about the criteria of ideal absorbent to be used during menstruation. But it was found that they were aware least $2(1.1 \%)$ about how often the absorbent be changed. The respondents had the better awareness regarding others factors like washing the genital organs 120 (65.2\%), changing of sanitary pad 137 (74.5\%), disposing of sanitary pad 136 (73.9\%) and washing of genital organs during menstrual period 165 (89.7\%) (Table 1).

\begin{tabular}{|lc|}
\hline $\begin{array}{l}\text { Table 1. Awareness of the respondents related to } \\
\text { menstrual hygiene. }\end{array}$ & $\mathrm{n}(\%)$ \\
\hline Particulars & \\
Meaning of menstrual hygiene & $156(84.8)$ \\
Aware & $28(15.2)$ \\
Unaware
\end{tabular}

Ideally used as absorbent during menstruation

Aware

$176(95.7)$

Unaware

Pad/Cloth pad changed during menstruation

Aware

Unaware $182(98.9)$

Cleaning the cloth pad after use

Aware

Unaware

Washing the genital organs

Aware

120 (65.2)

Unaware

Changing Sanitary pad how should we decide to wipe the genital

Aware

$137(74.5)$

Unaware

Disposing the sanitary pad

Aware

136 (73.9)

Unaware

Washing genital organ

Aware

165 (89.7)

Unaware

$19(10.3)$

Majority 179 (97.3\%) of the total respondents were aware what the menstruation is but only 112 (60.9\%) knew the causes. Majority 180 (97.8\%) of them aware about the period of menstrual blood flow, organ from which menstrual bleeding occurs 177 (96.2\%) but majority 167 (90.8\%) of them were unaware about the meaning of menstrual cycle, average cycle of menstruation 46 (25\%) and amount of blood flow during this period $112(60.9 \%)$ (Table 2$)$.

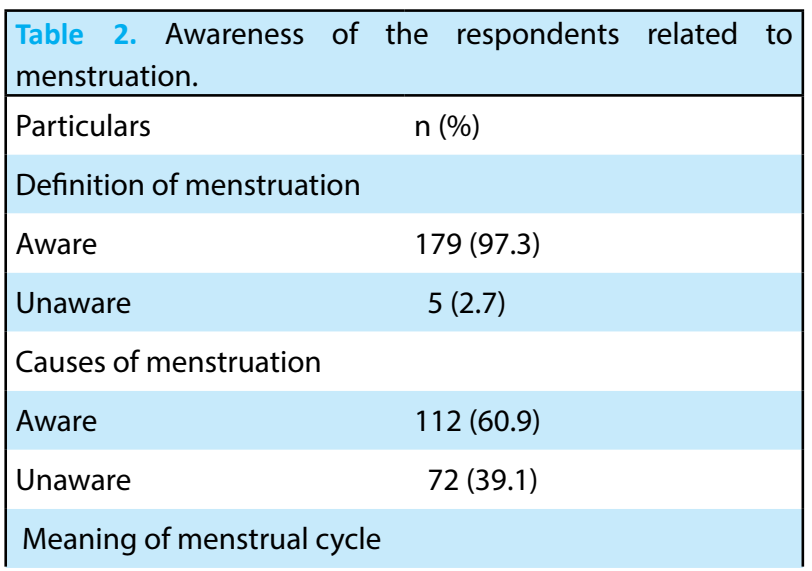




\begin{tabular}{|lr|} 
Aware & $17(9.2)$ \\
Unaware & $167(90.8)$ \\
Average cycle of menstruation & \\
Aware & $46(25.0)$ \\
Unaware & $138(75.0)$ \\
Period of menstrual & blood flow occur in normal \\
menstrual cycle & $180(97.8)$ \\
Aware & $4(2.2)$ \\
Unaware & $72(39.1)$ \\
Amount of blood flow during period & \\
Aware & $112(60.9)$ \\
Unaware & $177(96.2)$ \\
Organs from which menstrual bleeding occurs \\
Aware & $7(3.8)$ \\
\hline
\end{tabular}

The mean age of the respondent was $14.48 \pm 1.259$ years. Most $92(50 \%)$ of the respondents were of the age group 15 to 17 years and least $1(0.5 \%)$ belonged to age group of 18 to 20 years. Most $86(46.7 \%)$ of respondents belonged to Janajati ethnicity, about two third 145 (78.8\%) were Hindus (Table 3).

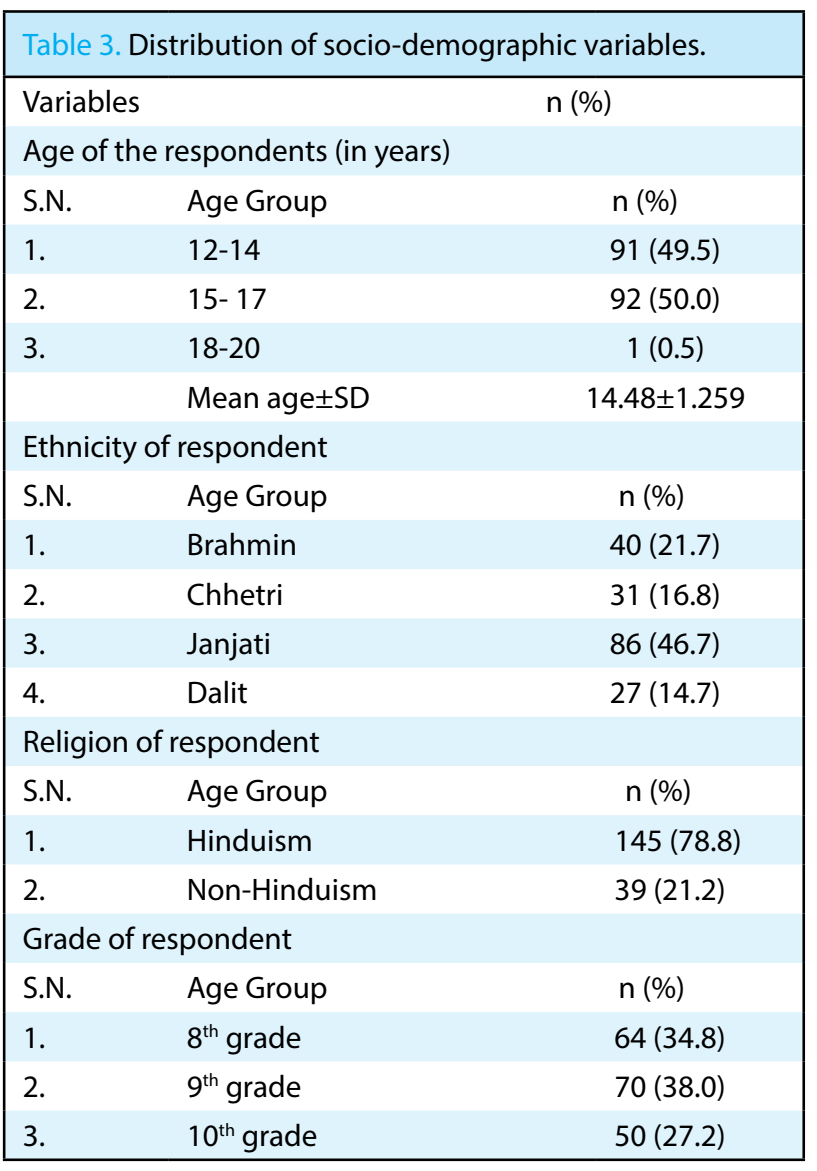

\section{DISCUSSION}

The finding of the study shows that $97.3 \%$ of the total respondents were aware what the menstruation is but only $60.9 \%$ knew the causes. One of studies showed that only $31 \%$ believed that menstruation was a normal physiological process, ${ }^{6}$ that very findings are contraindicated by the present study. Similarly, this result was contraindicated by another study which showed that only $36.7 \%$ of girls knew that it is caused by hormones, $6.0 \%$ of girls knew that menstruation is a normal physiological process.?

The present study shows that $84.8 \%$ of the respondents knew that menstrual hygiene is maintaining proper perineal hygiene during menstruation which is similar to the study which showed that $81 \%$ respondents knew about meaning of menstrual hygiene. ${ }^{8}$

The present study findings show that $97.8 \%$ of the respondents have the knowledge that period of menstrual blood flow is 3-7 days. Similarly, a study showed that 79 $\%$ respondents answered that period of menstrual blood flow is 3-7 days. ${ }^{9}$ This finding is also consistent with another study, where $83.3 \%$ respondents answered that period of menstrual blood flow is 3-7 days. ${ }^{10}$

Recent study indicates that $98.9 \%$ respondents have no knowledge that to avoid infection and odour, pad should be changed every 4 hours per day. Similar study showed that only $1.1 \%$ of respondents were aware that to avoid infection and odour pad should be changed every 4 hours per day. ${ }^{11}$

The findings of the study show that $95.7 \%$ respondents opined that new clean cloth and sanitary pad is the ideal absorbent to be used during menstruation. This finding is also similar with study findings, where $97 \%$ women opined that sanitary pad is the ideal absorbent to be used during menstruation. ${ }^{10}$

\section{CONCLUSIONS}

Awareness regarding menstrual hygiene was high among the girl students, but practice for proper menstrual hygiene was low comparted to studies done in similar settings. Still most of them were not aware of the hygienic practices to avoid infection, odour and frequency to change the sanitary pads.

\section{ACKNOWLEDGEMENTS}

I acknowledged to the help of Professor Dr. Daya Ram Lamsal of Emergency Department and all staffs of Emergency Department of Chitwan Medical College teaching hospital as well as School teachers chairman of village development Committee. I also express 
gratitude to my family and friends, who helped me entirely throughout my study. At last but not least all the respondents who participated in the study were so much thankful entire my heart.

Conflict of Interest: None.

\section{REFERENCES}

1. Abioye-Kuteyi EA. Menstrual knowledge and practices amongst secondary school girls in lle lfe, Nigeria. J R Soc Promot Health. 2000 Mar;120(1):23-6. [PubMed]

2. Baisley K, Changalucha J, Weiss HA, Mugeye K, Everett $\mathrm{D}$, Hambleton I, et al. Bacterial vaginosis in female facility workers in north-western Tanzania: prevalence and risk factors. Sex Transm Infect. 2009 Sep;85(5):370-5. [․ㅏbMed | Full Text $\mid$ DOI]

3. Aniebue UU, Aniebue PN, Nwankwo TO. The impact of pre-menarcheal training on menstrual practices and hygiene of Nigerian school girls. Pan Afr Med J. 2009 Jun 29;2:9. [PubMed | Full Text]

4. Ali TS, Rizvi SN. Menstrual knowledge and practices of female adolescents in urban Karachi, Pakistan. J Adolesc. 2010 Aug;33(4):531-41. [ubMed | Full Text | DOI]

5. Mahon T, Fernandes M. Menstrual hygiene in South Asia: a neglected issue for WASH (water, sanitation and hygiene) programmes. Gender and Development. 2010 Mar;18(1):99-113. [Full Text]

6. Tiwari H, Oza UN, Tiwari R. Knowledge, attitudes and beliefs about menarche of adolescent girls in Anand district, Gujarat. East Mediterr Health J. 2006 May-Jul;12(3-4):428-33. [PubMed | Full Text]
7. Adhikari P, Kadel B, Dhungel SI, Mandal A. Knowledge and practice regarding menstrual hygiene in rural adolescent girls of Nepal. Kathmandu Univ Med J. 2007 Jul-Sep;5(3):382-6. [PubMed]

8. Dhingra R, Kumar A, Kour M. Knowledge and practices related to menstruation among tribal (Gujjar) adolescent girls. Studies on Ethno-Medicine. 2009 Jan 1;3(1):43-8. [․ㅏll Text $\mid$ DOI]

9. Adinma ED, Adinma JI. Perceptions and practices on menstruation amongst Nigerian secondary school girls. Afr J Reprod Health. 2008;12(1):74-83. [PubMed]

10. Santra S. Assessment of knowledge regarding menstruation and practices related to maintenance of menstrual hygiene among the women of reproductive age group in a slum of Kolkata, West Bengal, India. Int J Community Med Public Health. 2017 Feb 22;4(3):708-12. [ Full Text | DOI]

11. Dasgupta A, Sarkar M. Menstrual hygiene: how hygienic is the adolescent girl? Indian J Community Med. 2008 Apr;33(2):77-80. [uuㄹed | Full Text | DOI]

(c) The Author(s) 2018.

This work is licensed under a Creative Commons Attribution 4.0 International License. The images or other third party material in this article are included in the article's Creative Commons license, unless indicated otherwise in the credit line; if the material is not included under the Creative Commons license, users will need to obtain permission from the license holder to reproduce the material. To view a copy of this license, visit http://creativecommons.org/licenses/by/4.0/ 